\title{
A TRILOGY OF MELANCHOLY \\ On the bittersweet in Before Sunrise, Before Sunset and Before Midnight
}

Hans Maes

NB: This paper will appear in Philosophers on Film: Before Sunrise, Before Sunset, Before Midnight, eds. H.Maes \& K. Schaubroeck, Routledge, 2021. This is a draft version. I am currently revising the paper and would welcome any suggestions for improvement.

Melancholy is a central expressive property of the Before films and key to understanding and appreciating the trilogy as a whole. That, in a nutshell, is the thesis I wish to develop in this paper. Melancholy is understood here as the profound and bittersweet emotional experience that occurs when we vividly grasp a harsh truth about human existence in such a way that we come to appreciate certain aspects of life more deeply. The various encounters between Celine and Jesse, I will argue, are littered with such moments of melancholy. These moments are partly prompted by the circumstances in which they find themselves, but both of them also actively seek out this experience by the stories they tell and the reflections they engage in. That seems part of who they are as individuals and it may even be part of what attracts them to each other. Melancholy, furthermore, is not just present in the characters' dialogue and in their facial and bodily expressions, but is also expressed through various cinematic means. And, as I will suggest in the final section, the films may resonate deeply with some viewers because they are so expressive of melancholy.

\section{Melancholy}

In the course of history the term 'melancholy' has been used in a variety of ways to refer to a particular character trait, a mood, various sorts of psychological pathologies, and even a form of cultural decline (Bowring 2016). Nowadays, too, people may think of melancholy as a type of sustained sadness or as a form of depression or morosity. However, this is not the kind of melancholy that I am primarily interested in and that I think is relevant in understanding the Before trilogy. When I use the term melancholy, I will use it exclusively to refer to a particular emotion. It is an emotion that is characterized by its bittersweetness, as well as its complexity and profundity. People who experience it usually value it quite highly and they may seek it out in their engagement with novels, poems, songs, paintings or films. So it is an emotion that can be evoked by, and expressed in, works of art.

Let me give some examples. Anton Chekhov and Lev Tolstoy, two giants of Russian literature, both had an extraordinary ability to express a sense of melancholy. Here is a passage from Chekhov's famous short story, The Lady With the Dog (1899):

Yalta was hardly visible through the morning mist; white clouds stood motionless on the mountain-tops. The leaves did not stir on the trees, grasshoppers chirruped, and the monotonous hollow sound of the sea rising up from below, spoke of the peace, of the eternal sleep awaiting us. So it must have sounded when there was no Yalta, no Oreanda here; so it sounds now, and it will sound as indifferently and monotonously when we are all no more. And in this constancy, in this complete indifference to the life and death of each of us, there lies hid, perhaps, a pledge of our eternal salvation, of the unceasing movement of life upon earth, of unceasing progress towards perfection. Sitting beside a young woman who in the dawn seemed so lovely, soothed and spellbound in these magical surroundings - 
the sea, mountains, clouds, open sky - Gurov thought how in reality everything is beautiful in this world when one reflects: everything except what we think or do ourselves when we forget our human dignity and the higher aims of our existence.

And this is from Tolstoy's War and Peace (1869):

After dinner Natasha, at Prince Andrei's request, went to the clavichord and began to sing. Prince Andrei stood by a window, talking to the ladies, and listened to her. In the midst of a phrase he fell silent and suddenly felt choked with tears, a thing he had thought impossible for him. He looked at Natasha as she sang, and something new and joyful stirred in his soul. He had decidedly nothing to weep about, but he was ready to weep. About what? His former love? The little princess? His disappointments? ... His hopes for the future? ... Yes and no. The main thing he wanted to weep about was a sudden, vivid awareness of the terrible opposition between something infinitely great and indefinable that was in him, and something narrow and fleshly that he himself, and even she, was. This opposition tormented him and gladdened him while she sang. ${ }^{\text {' }}$

The songs Pancho and Lefty (Townes van Zandt), Twee Meisjes (Raymond van het Groenewoud), Autumn Letter (가을 편지, Kim Min-Ki), and Bella Ciao (as sung, for instance, by Goran Bregovic or the characters of Berlin and the Professor in La Casa de Papel) are also good examples, as are the films Underground (1995, dir. Emir Kusturica), Barry Lyndon (1975, dir. Stanley Kubrick), and Late Spring (1949, dir. Ozu).

Each of these songs and films, and each of the quoted passages, is soaked in melancholy. But what exactly is distinctive of that emotion as it is expressed in these works? Here is my semitechnical definition: melancholy is a complex emotional process triggered by the affective appraisal of (what is perceived to be) a profound but typically harsh truth about human existence that puts the precarious value of something that you (feel you should) care about in sharp relief in such a way that you come to appreciate it more deeply. As a result, negative feelings or emotions (e.g. sadness, grief, desolation) will co-occur or alternate with positive feelings or emotions (e.g. joy, gratitude, peacefulness).

Some clarifications are in order. The existential truths that give rise to melancholy can be varied in nature. They can relate to the transience of all things, the indifference of the universe to the life and death of each of us (as in Chekhov), the 'terrible opposition' we find in ourselves 'between something infinitely great and indefinable ... and something narrow and fleshly' (as in Tolstoy), etc. But it is key that such truths are not just theoretically acknowledged. In order for there to be a real emotion, they need to be vividly grasped or 'affectively appraised.' According to Jenefer Robinson, affective appraisals 'are always in terms of one's own goals, interests, wants, or wishes. I respond emotionally when my interests or those of my group (me or mine) are perceived to be at stake' (2005: 109). One could certainly apprehend, say, the general idea of mortality in a cool and detached way. Yet it is only when you start to grasp the implications for yourself (or those close to you) that an emotional response might ensue. As Tolstoy reflects in The Death of Ivan Ilyich:

"Caius is a man, men are mortal, therefore Caius is mortal" had always seemed to him correct as applied to Caius but certainly not as applied to himself. That Caius - man in the abstract - was mortal was perfectly correct, but he was not Caius, not an abstract man, but a creature quite, quite separate from others.

Only when the main character realizes that he is in fact not different from others and that death awaits him, too, is he plunged into the emotional turmoil that is at the heart of the story.

Of course, when someone really comes to grasp a harsh existential truth, their response may just be one of sadness, horror, or despair. But it can also be more complex and multifaceted. And 
that's when melancholy may ensue. The harsh existential truth may come to accentuate the precarious value of something that you (feel you should) care about - the present moment, a past friendship, your lifelong partner - in such a way that you come to appreciate that something or someone more deeply. This gives rise to more positive feelings or emotions that help to offset the initial feelings of sadness or despair. Hence the bittersweet nature of melancholy and the sad subdued smile or tearful happiness that often accompany it.

Moments of melancholy can be quite brief and subtle when there's a quick shift of the negative to the positive. But the whole process can also be protracted and very intense, with thoughts that are continuously developing and overlapping, affecting and even looping back on each other, resulting in a prolonged alternation of the bitter and the sweet. A famous example of this is the ending of James Joyce's The Dead (1914), where we are made privy to the melancholic reflections of the protagonist Gabriel. He has just come to the painful realization that he has not been his wife's one-and-only true love and they were not necessarily meant to be together because she did love someone else a long time ago. But 'as he thought of what she must have been then, in that time of her first girlish beauty, a strange friendly piety for her entered his soul.' (Joyce 1969: 223). Gabriel continues to ruminate on the events of the day, on his own foolish pretensions, and on sickness and death that will inevitably come upon his family. And then: 'The air of the room chilled his shoulders. He stretched himself cautiously along under the sheets and lay down beside his wife. One by one they were all becoming shades. Better pass boldly into that other world, in the full glory of some passion, than fade and wither dismally with age. He thought of how she who lay beside him had locked in her heart for so many years that image of her lover's eyes when he had told her that he did not wish to live. Generous tears filled Gabriel's eyes.' (Joyce 1969: 223). The story then ends with one of the most beautifully melancholic paragraphs in world literature (the poignancy of which was exquisitely transferred to the silver screen by John Huston in his film adaptation of The Dead).

Melancholy is not always or necessarily aesthetic in nature. But in those cases where melancholy leads to a deeper aesthetic appreciation, we could consider it as an aesthetic emotion. To put it differently, we may speak of aesthetic melancholy if and when an aesthetic experience is integrated into the complex emotional process described above. An aesthetic experience occurs, some have argued, 'when we value our aesthetic perception of an object for its own sake and are moved in virtue of that perception' (Jerrold Levinson quoted in Maes 2017: 28). If that is so, then it seems that the characters in the passages I quoted from Tolstoy, Chekhov, and Joyce are indeed experiencing aesthetic melancholy. Prince Andrei appreciates the beauty of Natasha's music and is deeply moved in virtue of it. Gurov is aesthetically savouring his surroundings whilst being in the thralls of melancholy. And the same goes for Gabriel in The Dead. He is not only moved by the beauty of his sleeping wife but his soul 'swooned slowly as he heard the snow falling faintly through the universe and faintly falling, like the descent of their last end, upon all the living and the dead.' (Joyce 1969: 224). Moreover, readers of Tolstoy, Chekhov and Joyce may also be experiencing aesthetic melancholy in savouring these beautiful passages. When you read about the 'eternal sleep awaiting all of us' or the world's 'complete indifference to the life and death of each of us' you are invited to contemplate these existential truths. And doing so may put the precarious value of beauty, and particularly the beauty and artistry of the prose you are reading, in sharp relief in such a way that you come to appreciate it more deeply.

\section{The characters}

In all three films there are key scenes where the characters are unmistakably experiencing and expressing melancholy, in the way that I have defined it. In Before Sunrise there is Jesse's recital of the W.H. Auden poem that presses home the thought that time cannot be conquered and 'will have his fancy, tomorrow or today'. As the poem sinks in, the bond between the two seems stronger than ever. The playful flirtation has made room for a deeper longing and they now seem ready to savour 
the remaining moments they still have together. Later, at the very end of the film, when they've separated and are traveling alone - Jesse on the bus and Celine on the train - we see the sad but appreciative smile that is so typical of melancholy on both their faces. They are happy to have had this adventure, even though the adventure had to come to an end. Or perhaps I should say, because it had to come to an end. That, at least, seems to be their own view:

JESSE: Everything is so finite. I mean, but don't you think that that's what makes our time, at specific moments, so important?

CELINE: Yeah, I know. It's the same for us, tonight, though. After tomorrow morning, we're probably never going to see each other again, right?

They make a conscious decision to enjoy their one night together knowing that they will have to part in the morning:

JESSE: So, you think tonight's it, huh? I mean, that tonight's our only night.

CELINE: It's the only way, no?

JESSE: Well, alright. Let's do it. No delusions, no projections.

CELINE: Okay, let's do that.

Melancholy is also the overriding feature of one of the pivotal moments In Before Sunset, namely Celine's touching monologue on the 'little things':

I feel I was never able to forget anyone I've been with. Because each person has their own, specific qualities. You can never replace anyone. What is lost is lost. (...) I will miss of the other person the most mundane things. Like I'm obsessed with little things. Maybe I'm crazy, but... when I was a little girl, my mom told me that I was always late to school. One day she followed me to see why. I was looking at chestnuts falling from the trees, rolling on the sidewalk, or... ants crossing the road, the way a leaf casts a shadow on a tree trunk... Little things. I think it's the same with people. I see in them little details, so specific to each of them, that move me, and that I miss, and... will always miss. You can never replace anyone, because everyone is made of such beautiful specific details. Like I remember the way, your beard has a bit of red in it. And how the sun was making it glow, that... that morning, right before you left. I remember that, and... I missed it!

In Before Midnight it is the central dinner table scene and Natalia's speech in particular where we find the clearest expression of melancholy. She is reminiscing about her late husband Elias (in a way that is noticeably reminiscent of Celine's monologue in the earlier film):

But lately I've been forgetting little things. He's sort of fading and I'm starting to forget him and it's like losing him again. Sometimes, I make myself remember every detail of his face the exact colour of his eyes, his lips, his teeth, the texture of his skin, his hair - that was all gone by the time he went. And sometimes, not always, but sometimes I can actually see him. It is as if a cloud moves away and there he is. I could almost touch him, but then the real world rushes in, and he vanishes again. For a while, I did this every morning, when the sun was not too bright outside because the sun somehow makes him vanish. He appears and he disappears like a sunrise or sunset, anything so ephemeral. Just like our life - we appear and we disappear and we are so important to some, but, we are just passing through.

Her words resonate with another melancholic scene in which Celine and Jesse are seated on a terrace, watching an ephemeral sunset disappear behind the mountains. They are cherishing the 
warmth of the moment in the knowledge that it will soon be gone (just like, quite possibly, their relationship might soon come to an end).

So far, I have focused on scenes where the emotion of melancholy is very pronounced. But as was mentioned in the previous section, while melancholic episodes can be intense and protracted, they can also be more subdued and relatively short-lived. Each of the Before film is in fact dotted with such brief and often very subtle moments of melancholy. A nice example in Before Sunrise is when they spot the poster for the Seurat exhibition. Celine says: 'I love the way the people seem to be dissolving into the background. It's like the environments are stronger than the people. His human figures always seem so transitory.' The comment is followed by a gentle pause and while the camera lingers on a drawing of a deathbed scene we hear a church bell ring. Immediately afterwards, when they're in the church, Celine makes a comment that is similarly laced with melancholy:

I was in an old church like this one with my grandmother in Budapest a few days ago. Even though I reject most of the religious thing, I can't help but feeling for all those people that come here lost, or in pain, guilt - who come here looking for answers. It fascinates me how a single place can join so much pain and happiness, for so many generations.

In Before Sunset they are savouring the sight of another church, Notre-Dame de Paris, when Celine makes this observation (that becomes even more poignant in light of the disaster that took place in 2019): 'But you have to think that Notre-Dame will be gone one day. There used to be another church at the Seine, right there.' And in the last film it is yet another religious building, the small chapel of Saint Odilia with its faded wall paintings, that prompts Jesse to muse on the idea of impermanence and to tell the story of the monks who paint with water on rock on a hot day so that by the time they're done the paintings have already evaporated.

It is not just the places they find themselves in that elicit melancholic reflections in our characters. It is also the particular timeframe of their encounters that is eminently conducive of melancholy. Firstly, there is the sunset, the most melancholic moment of the day. When the light is fading and the activities of the day have ceased, one is easily filled with thoughts of transience. At the same time, of course, a sunset gives one occasion to appreciate the beauty of the 'golden hour' or the gifts of the day that has just gone. It is telling that a melancholy sunset features prominently in all three films (the terrace scene in Before Midnight, the boat trip in Before Sunset, the first kiss in Before Sunrise). Moreover, in each of the films the two main characters meet so-to-speak under a ticking clockii: Jesse has a plane to catch in Before Sunrise and Before Sunset, while in Before Midnight they only have one night together, free of child care, before they have to head back home. So they cannot but be aware that time is limited and fleeting. The fact that each of their encounters is marked by something important coming to an end only reinforces this idea. In Before Midnight Jesse has just said goodbye to his son. It's the end of summer and the end of their holiday in Greece. iii In Before Sunset it's the last stage of Jesse's long book tour. And in Before Sunrise, Celine is returning from a visit to her beloved grandmother while Jesse is bringing his disastrous but formative Europe trip to an end.

Lest there be any misunderstanding, however, Celine and Jesse are not just drawn to melancholy because of the physical environment or the temporal circumstances in which they find themselves. Even in the absence of any external cue, they seem to be seeking it out, as they spontaneously engage in melancholic reflections throughout their conversations. Where other people might dwell on everyday particularities, Celine and Jesse will typically use such particularities as springboards to talk about more general aspects of human existence. They are continuously putting things in a broader perspective as a way to maintain, convey or achieve a clear view of what they really care about. This is also evident in the stories they tell each other, often a propos of nothing. These stories tend to have a melancholic punch line, like the story of Celine's friend George in Before Midnight. He found out that he had an incurable disease with only nine months to live, but 
this did not drive him to despair. On the contrary, "he was finally able to enjoy everything about life, even like being stuck in traffic. He would just enjoy looking at people... staring at their faces. Just little things.' (Note the reiteration of that significant little phrase here.)

The story of George appears as an interesting mirror image of the one that Jesse tells in Before Sunrise.

Jesse: I remember my mother once, she told me, right in front of my father - they were having this big fight - that he didn't really want to have me, you know, that he was really pissed off when he found out that she was pregnant with me; you know, that I was this big mistake. And I think that really shaped the way I think. I always saw the world as this place where I really wasn't meant to be.

\section{Celine: That's so sad.}

Jesse: No, I mean... I eventually kind of took pride in it...like my life was my own doing or something... like I was crashing 'The Big Party.'

In the second film, too, there are melancholic mini-stories. For instance, Jesse mentions how he went to a Trappist monastery and really began to appreciate the monks' lifestyle: how they were quick to laugh, easy to be around, very attuned to everything. And he contrasts this with the hustle and bustle of everyday existence: 'You realize that most of the people that you meet are trying to get somewhere better, trying to make a little bit more cash, trying to get a little more respect, have more people admire them, you know... it's just exhausting!' Another example is the story Jesse tells about being in a band and being preoccupied with the future rather than enjoying the present. Or the story he wants to incorporate in his next book, about a man who has made it - good job, beautiful wife, nice house - but who comes to realize that happiness is in the doing, not in getting what you want, and who is subsequently moved by his 5 year old daughter dancing on top of a table.

To recapitulate, Jesse and Celine share many intense as well as more subtle moments of melancholy in their various encounters. These are partly prompted by the environment and the circumstances in which they find themselves. But both of them also actively seek out and create such moments by the stories they tell and the reflections they engage in. That seems part of who they are as individuals. And, I now want to add in conclusion, it seems part of what attracts them to each other.

Right from the start, in Before Sunrise, the two feel a special connection. I think it is not too far-fetched to suspect that it is their mutual appreciation of melancholy that helps to explain why they feel this special bond. As Brady and Haapala (2003) have pointed out, solitude forms the characteristic backdrop of melancholy because the solitary state is so eminently conducive of reflection. However, melancholy can sometimes be experienced and explored in company. But the conditions have to be right: you and your conversation partner(s) need to be similarly inclined to face up to certain existential truths and you need to value and take pleasure in roughly the same aspects of life (the ones that are accentuated by the contrast with those difficult existential truths). Those conditions are rarely fulfilled, but they clearly are when our two main characters meet in the Before trilogy. Jesse and Celine share a penchant for melancholic musings and it seems that they are, at least in part, drawn to each other because of it.

It's quite telling, for instance, what Celine says when she's asked (in the scene of the pretend phone conversation in Before Sunrise) why she got off the train with Jesse. The moment she fell for him, she confesses, is when he told the beautifully bittersweet childhood story of seeing his great grandmother who had just passed away through the mist of a garden hose. Likewise, in Before Sunset, it is after Celine's melancholic reflections on the "little things" that Jesse confesses his hopeless and continuing attraction to her: 'Oh, God. Why didn't we exchange phone numbers and stuff?' 


\section{The film}

Melancholy is manifestly present in the characters' dialogue and in their facial and bodily expressions. But 'film expression' is not exhausted by what we might label 'character expression'. There are other ways in which films may express emotions. In this section, I will argue that the Before films also express melancholy via (1) the soundtrack, (2) the recurrent use of certain stylistic devices such as the 'Ozu sequence' and (3) the 'stealing glances sequence', (4) some notable motifs, and (5) various filmic references.

(1) Before Sunrise opens with the overture to Purcell's Dido and Aeneas, which is spirited and lively but has a melancholic undertone that only becomes more pronounced if you know the story of Dido and Aeneas, the lovers who were eventually forced to part. Similarly, the first music we hear in Before Midnight is the instrumental piece The Best Summer of My Life written for the film by Graham Reynolds. It starts slow and sad during what the filmmakers have dubbed the 'fallout scene', i.e. the scene at the airport where we witness the fallout of Jesse's decision to abandon his marriage (and part with his son) for a life with Celine. But the music picks up when he exits the airport and Celine finally comes into view, giving the overall piece a distinctly bittersweet feeling.

Melancholy is expressed even more clearly and explicitly in the various songs that are used throughout the trilogy. Take Julie Delpy's An Ocean Apart that is the opening track of Before Sunset. The chorus of that song serves up a tough existential truth ('Time goes by and people cry and everything goes too fast'), while the verses describe moments that are to be cherished ('Now we are together/Sitting outside in the sunshine' or 'Now we have each other/Enjoying each moment with one another'). The ending of Before Sunset, with Celine dancing to Nina Simone's Just in Time, also bathes in melancholy. While some of the lyrics of the song appear optimistic ('No more doubt, no more fear, I have found my way, your love came just in time') the song is mainly sung in an elegiac tone with a voice that seems to come from a place of suffering ('I was lost them losing dice were tossed/My bridges all were crossed nowhere to go'). Suffering and death are also part of the context in which the song is set in the film. Celine and Jesse have just had a bitter altercation in the car where they've opened up about the misery in their respective lives. When he enters her apartment he sees a photo of 'little cross-eyed Celine' with her grandmother and we are reminded of the grandmother's death and how it was her funeral that kept the two lovers apart. And then during the opening verse of Just in Time it is the recent death of Nina Simone they ruminate about. Set against such a background the already poignant song becomes even more poignant. Finally, the song that plays over the closing credits of Before Sunrise, Kathy McCarthy's Living Life, also has the typical duality of melancholy. Troubling existential concerns ('When everything's so tasteless/And all the colours seem to have faded away' or 'Because I'm learning to cope/With the emotion-less mediocrity') are punctuated with the injunction to nevertheless cherish the one life you have ('This is life/And everything's all right/Living life').

(2) The 'Ozu sequence'. That is the way Richard Linklater has referred to the stylistic device employed in all three films whereby a slow series of shots shows the main locations of the story in the absence of the principal characters. The shots come at steady intervals and are filmed with a stationary camera that lingers long enough on each site to bring the viewer in a contemplative mood. The effect is mesmeric. And, as we know from the gentle, bittersweet cinema of Ozu, it is a device that is eminently suitable to express melancholy.

In Before Sunrise the sequence comes at the end of the film. Dawn is breaking and ordinary life resumes in those places where Celine and Jesse have spent the night of their lives. It speaks powerfully of the fact that everything must end sometime. In the final shot of that sequence we even see an old lady trundling past the bottle of wine the two lovers have left behind in the park, turning this tableau into a moving 'memento senescere'. And that's not all. The cherished places of their budding romance - the bridge where they start their journey through Vienna, the amusement 
park where they kiss, the statue where Jesse recites the poem - appear without lustre in the stark morning light. Cars and people just pass by without taking special note. The sequence thus conveys, in a soft and subtle way, the difficult truth that others will likely be indifferent to the places and things that are of the utmost significance to us. The sites of momentous occasions in our lives are just part of banal everyday existence for other people. (I am reminded here of a passage in W.G. Sebald's Austerlitz: 'how everything is constantly lapsing into oblivion with every extinguished life, how the world is, as it were, draining itself, in that the history of countless places and objects which themselves have no power of memory is never heard, never described, or passed on' (Sebald 2011: 30-31).

In Before Sunset the Ozu sequence comes at the start of the film. We see various locations in Paris - a street corner, a café, a quiet courtyard - before the film cuts to Jesse and the reporters in the bookshop Shakespeare \& Co (one of the many nods to the work of James Joyce). ${ }^{\text {iv }}$ The melancholic character of this opening sequence is only revealed on a second viewing. Because it's only then that we come to realize that what seemed like a banal series of touristy shots of Paris is in fact a carefully constructed montage of the various places where Celine and Jesse will have their lifechanging second encounter. So, upon re-watching the film, the viewer comes to realize that she herself is (inevitably?) like those indifferent passers by at the end of Before Sunrise who take no special note of the places and things that are of utmost importance to other people.

The Ozu sequence in Before Midnight is clearly meant as a continuation of those previous sequences in Before Sunset and Before Sunrise. But it also stands out for a number of reasons. To begin with, no exterior scenes are shown here, but we rather get to see the interior of a hotel room. Moreover, the sequence doesn't come at the very end or at the very beginning of the film, but is inserted as the story is still unfolding. And, most importantly perhaps, while the sequence in the other two films is presented from a third-party perspective, here it comes as a series POV shots from the perspective of Jesse (see MacDowell 2013 for why this choice might not be unproblematic). He's surveying the hotel room as if it were an abandoned battleground. Through his eyes the viewer, too, is reminded of the petty fights that took place here and the deeper disappointments that have come to the surface. At the same time, we are also reminded of the earlier love scene on the bed. And the abandoned wine bottle may take us back to the first film and the wine bottle they obtained for their very first night together. The sequence is profoundly melancholic. It evokes the pain and difficulties that come with a long-term relationship but also conveys (as the filmmakers are keen to point out in the commentary track) that there is still love, that there is still something worth saving. ${ }^{\vee}$ The way this scene is set up, by the way, is powerfully and (I think) deliberately reminiscent of the final scene in both James Joyce's and John Huston's The Dead, where Gabriel is also surveying his hotel room as if it were an abandoned battleground: 'His eyes moved to the chair over which she had thrown some of her clothes. A petticoat string dangled to the floor. One boot stood upright, its limp upper fallen down: the fellow of it lay upon its side. He wondered at his riot of emotions of an hour before. From what had it proceeded?' (Joyce 1969: 223).

(3) In all three films there is what I want to call the 'stealing glances sequence'. The most memorable of these, perhaps, occurs in Before Sunrise. Celine and Jesse have entered the listening booth in the record store to play Kath Bloom's Come Here. As the script says: 'They glance subtly up at each other but usually not when the other is looking. The song makes both of them a little nervous as it brings out a shyness about the uncertainty of their relationship at that point.' (Linklater 2008: 42) The characters themselves are not melancholic - they are shy and nervous and full of longing - but the scene has a definite melancholic undertone. The tender and slightly sad song in combination with their furtive and bashful glances captures the beautiful fleetingness of a budding romance. If their glances were to meet, they could be assured of each other's feelings. But their eyes never interlock and so the fleeting moment in which they could seal their romance passes. Luckily for Celine and Jesse they will get another opportunity, but - and this is a thought that will no doubt resonate with some viewers - such a second chance is not given to everyone. ${ }^{\mathrm{vi}}$ 
In Before Sunset the stealing glances sequence happens when they're walking up the stairs to Celine's apartment and a similar sort of uncertainty and longing fills the air. But already in the scene that comes before that, when they're in the car and confessing to the misery in their lives, their glances fail to meet at crucial times. Celine wants to touch and comfort Jesse but he fails to notice this, and vice versa. The opportunity for an embrace passes by and the audience is again reminded of the fact that the right moment might be lost - a bitter truth that makes the sweetness of a possible reunion stand out even more.

In Before Midnight it is the final scene, at midnight on the terrace, that presents us with the uncertainty of whether their glances will meet and whether they will be able to make up and remain together as a couple. As the camera slowly pulls away, they do seem to re-engage but the bittersweet music leaves us wondering whether this is only a temporary reprieve.

(4) There are some notable motifs throughout the trilogy that lend further support to the idea that melancholy is key to understanding these films and that the harsher truths of human existence always serve to accentuate the central romance between our two beautiful and young(ish) protagonists. One such motif is that of the grandmother and, by extension, that of old age. It's there in Before Midnight where Jesse receives the news of his grandmother passing away, and where a grand old couple, Natalia and Patrick, preside over the dinner table and meditate on the passing of time. It's there in Before Sunset where, early on, we learn that it was the funeral of Celine's grandmother that prevented her from meeting him again in Vienna. Later on, Jesse (and the viewer) gets to a see a picture of Celine's grandmother and is reminded of the time that has since slipped away. But the motif is, surprisingly perhaps, most prominently present in the first film, Before Sunrise. Not only do Celine and Jesse repeatedly talk about their (great-)grandmothers in their various melancholic ponderings, but the film is also dedicated to the director's grandparents. And, as we've already seen, the film ends with the poignant 'memento senescere' of the old lady walking past the empty bottle of wine.

Another recurrent motif that is meant to offset, however briefly, the sweetness of romance is that of war. In Before Sunrise Celine draws attention to the fact that there's a war going on, and that people are dying, less than three hundred kilometres from Vienna. In Before Sunset Jesse mentions the war that could have destroyed the Notre-Dame (but didn't). In Before Midnight he recounts how the occupying army of Turks was responsible for scratching out the eyes of the beautiful icons they encounter in the shrine. Celine later reminds him that politicians going to war for no reason is just one example of how 'the world is fucked by unemotional rational men deciding shit'.

(5) Finally, there are some extra scoops of melancholy for the cinephile hidden in this trilogy. The films are laden with cinematic references and it's revealing that most of these references are to movies that are through and through melancholic. Let me list some examples (besides the 'Ozu sequence' that I have already discussed).

Before Sunrise references two melancholic masterpieces that are also set in Vienna. One is The Third Man (1949, dir. Carol Reed). Not only do Celine and Jesse kiss in the Ferris wheel that is the backdrop to the most famous scene in The Third Man, but they also have their 'men killing each other over a woman' conversation precisely when they pass the doorway where Harry Lime makes his long-awaited entrance. Moreover, the church they visit, where Celine talks about her grandmother in Budapest, is the Church of Maria am Gestade which already featured in The Third Man. Letter from an Unknown Woman (1948, dir. Max Ophüls) is the other classic set in Vienna that Linklater pays homage to. It also makes use of the Ferris wheel in the Prater, it has a memorable farewell scene at the train station, and the two protagonists spend one - and only one - night together rambling the streets of Vienna. (As Stefan says to Lisa: 'I suppose sooner or later we'll have to decide where we are walking to ... I almost never get to the place I set out for any way'). Furthermore, the scene where Celine and Jesse sit directly opposite one another in the train is framed in precisely the same way and intentionally brings to mind the scene of the amusement train ride in Letter from an Unknown Woman. 
Before Sunrise also contains some less obvious but equally revealing references. For instance, the rabbit that Celine and Jesse unexpectedly find in the cemetery is a direct homage to Some Came Running, the melancholic drama directed by Vincente Minelli that has a rabbit quivering in the grass in one of its crucial scenes. Or think of the tram ride in Murnau's Sunrise (1927) and the spinning scene from Truffaut's 400 Blows (1959) that seem to be reprised in Before Sunrise. ${ }^{\text {vii }}$ Some have also speculated that the play that Celine and Jesse are invited to early on in the film, Bring Me the Horns of Wilmington's Cow, is a reference to Sam Peckinpah's brutal but melancholic Bring Me the Head of Alfredo Garcia (1974).

In Before Sunset, Celine says 'maybe we're only good at brief encounters, walking around in European cities in warm climate', thereby alluding, so it seems, to Brief Encounter (1945, dir. David Lean), a film that resonates both thematically and affectively with this second instalment of the trilogy. She makes this comment when they're on a tourist boat in Paris - quite likely a reference to the bittersweet scene in Casablanca (1942, dir. Michael Curtiz), where Rick and Ilsa also take a Paris tourist boat. Additionally, it's been suggested that Agnès Varda's Cléo de 5 à 7 (1962), which has a similar time-frame as Before Sunset and is about a young woman in Paris coming to terms with her mortality, was a direct influence on Linklater (Stone 2013: 130).

One of the side characters in Before Midnight, Patrick, is played by Walter Lassally, who was the cinematographer of Zorba the Greek (1964, dir. Michael Cacoyannis). ${ }^{\text {viii }}$ That film, which is all about joy in the face of bleakness, is also set in Greece and has a writer as its main character. Moreover, the surprising shot of the goats in Before Midnight might be a nod to the important scene in Zorba where Irene Pappas's goat is abducted by the men in the village. However that may be, a film that is certainly an important reference point for Before Midnight is Roberto Rosellini's Journey to Italy (1954). In the car ride from the airport Celine explicitly mentions the film as she recalls one of its key scenes: 'I remember a couple walking through the ruins of Pompeii, looking at bodies that had been lying there for centuries. I remember the bodies caught in their sleep, still lovingly holding each other. I don't know why, sometimes I have this image in my mind when, you know, we're asleep and you hold me.' Journey to Italy also begins with a car ride and a long discussion between two partners who have been together for roughly 8 years. And there are many other parallels: the mutual recriminations, the looking at art and ruins and reflecting on the passing of time, the husband ogling other women, the unmistakable allusion to James Joyce's The Dead. In all sorts of ways the cinephile is invited to view Before Midnight through the lens of Journey to Italy and given the difficult existential truths that are front and centre in Journey, this certainly gives the film an extra melancholic layer. ${ }^{\text {ix }}$

\section{The audience}

The Before trilogy does not just express melancholy, as was argued in the previous section, but it is also highly expressive of that emotion. This distinction, between expression and expressiveness, is thematized by Jenefer Robinson (2007). Expression, she explains, should be thought of as a relation between an artwork and an expresser, who is either the artist or an imagined agent such as a narrator or a character in the work. Expressiveness, by contrast, should be thought of as a relation between the artwork and the audience to whom it communicates. 'Whether something is or is not an expression depends on whether it is a product of a person or agent who is expressing his or her emotions. Expressiveness, on the other hand, depends on how effectively the artwork reveals to a (suitable) audience what that emotion is like' (Robinson 2007). And Robinson adds: 'I have suggested that among the most effective ways of doing this is to evoke that emotion in the audience' (Robinson 2007). For example, someone might express her state of mind verbally by saying 'I feel melancholic'. That would be an expression of melancholy, but it wouldn't be very expressive. Alternatively, one could create a work of art and by means of a story or dialogue or music or purely 
visual means (or all of the above) induce the audience to feel melancholic and to learn what it is like to be in such a state. That, I posit, is what the Before films do.

The characters don't simply state that they are feeling melancholic. In fact, the word 'melancholy' is never once mentioned in the trilogy. But in a great variety of ways the films do offer us an insight into what it is like to be in that state and, at times, leave us feeling melancholic (in the way that I have defined that emotion). ${ }^{x}$ They do this better than, say, any photograph or painting of melancholy that I'm aware of. This, of course, is partly due to the nature of the medium. Paintings and photographs are static and mute. A painting or a photograph will typically depict one moment and so it is much more difficult for it to really capture the complex process and developing nature of melancholy (the bitterness and the sweetness). Paintings and photographs also cannot articulate and make explicit the musings that give rise to melancholy. Films, on the other hand, do not have these limitations. And the Before films in particular exploit all the means at their disposal - stories, dialogue, images, music - to reveal melancholy in all its complexity and variety: from the very intense and protracted to more subtle and subdued episodes, from the melancholy of twentysomethings to that of mid-life or old age, from the bittersweet feelings triggered by a 'memento mori' or 'memento senescere' to those prompted by other existential truths like the fact that each life will have its share of unfulfilled promises, or that it can be extremely challenging to maintain a passion as the years progress, or that there is always a war raging somewhere causing suffering to countless people while the rest of us live our peaceful lives.

It is, I think, because the films are so expressive of melancholy that they have resonated so deeply with some viewers. For the Before films are prone to hit home if you are the sort of person who can appreciate that bittersweet feeling of melancholy (as I have defined it). David Foster Wallace aptly describes the pang of recognition one can feel in engaging with fiction: 'There's a kind of Ah-ha! Somebody at least for a moment feels about something or sees something the way that I do. It doesn't happen all the time. It's these brief flashes and flames, but I get that sometimes. I feel unalone-intellectually, emotionally, spiritually. I feel human and unalone and that I'm in a deep, significant conversation with another consciousness' (Miller 2012: 62). Chances are, if you yourself have a penchant for 'la douleur exquise', that this is what you'll experience when you watch the Before trilogy. So, while I argued in an earlier section that a shared appreciation for melancholy is (at least in part) why the characters are attracted to each other, I want to suggest here that it may be the very same thing that helps to explain why many viewers are drawn to these films and why the trilogy has attracted such a cult following.

Now, integral to feeling deeply attracted to something (or someone) is the desire to revisit or to keep interacting with that something (or someone). And while none of the Before films was a blockbuster, the trilogy has earned itself a very loyal audience with many fans who have seen the films multiple times. Does it reward such repeated viewings (and I'm asking this question specifically with an eye to the prized feeling of melancholy)? The answer is 'yes'. The series has rich veins of melancholy that one can keep mining as an audience. Firstly, because each film is carefully constructed and multi-layered, there will be certain elements the poignancy of which one will only grasp on a second viewing. The clearest example of this is the 'Ozu sequence' in Before Sunset that I've already discussed. But there are other instances. Early on in Before Sunrise, when Celine describes her first sexual feelings towards a boy she met on a summer camp, she recounts how she and the boy promised each other to write and meet again but then didn't - a throwaway remark that acquires more significance in light of the later developments between herself and Jesse. ${ }^{\mathrm{x}}$ In Before Midnight Celine pronounces the sunset to be 'gone' whilst sitting on a terrace. It is that very same terrace that she will later return to after declaring that her love for Jesse is gone.

Secondly, what goes for the individual films, also goes for the trilogy as a whole. It is so carefully constructed that revisiting the first films in light of the final instalment, and vice versa, is rewarded with extra sparks of melancholy. For instance, the fight between the older couple in the train that effectively brings Celine and Jesse together in Before Sunrise will resonate differently for viewers who have seen Before Midnight. Such viewers will also be able to connect the passage in 
Before Sunrise where Celine says she loves the red in Jesse's beard with her observation in Before Midnight that the red in his beard has gone. The time-travelling bit that Jesse does in Before Midnight is a reprise of the time-travelling spiel that gets Celine off the train in Before Sunrise. Knowing this will add some sweetness to the scene in Before Midnight and, conversely, it may add some bitterness to the scene in Before Sunrise. Another example is the reference to Quaker weddings in both Before Sunrise and Before Midnight. The romantic admiration they express for this quiet ceremony in the first film will, for those who have seen the whole trilogy, be offset by the ironic and somewhat cynical tone they adopt in the final film. (Speaking more generally, the trilogy offers an easy recipe for melancholy in that it will be difficult for fans not to let the beautiful naivety of the younger couple be offset by the more jaded experience of the middle aged couple.)

A final note about aesthetic melancholy. As I have argued in the first section, melancholy is not always or necessarily aesthetic in nature. For instance, at the end of Before Sunrise, when Celine and Jesse have separated and are traveling alone, they seem to be in the thralls of melancholy (as I have defined it), but there's nothing particularly aesthetic about the emotion they experience at that point. However, melancholy can and often does go hand-in-hand with an aesthetic experience. It's when the contemplation of a harsh existential truth leads to a deeper aesthetic appreciation that we may speak of aesthetic melancholy. There are quite a few examples of this in the trilogy: when Celine and Jesse slowly watch the sun disappearing behind the mountains in Before Midnight, when they contemplate the beauty of Notre-Dame in Before Sunrise, or when they ruminate on Seurat's ephemeral figures in Before Sunrise.

Moreover, viewers of the trilogy may also come to experience aesthetic melancholy in savouring some of these scenes. When our main characters admire the Notre-Dame and reflect on how it narrowly escaped in WWII but will one day be destroyed, we as viewers are also invited to contemplate that harsh truth and to share in the aesthetic admiration for that magnificent cathedral. In Before Sunrise there is Jesse's poignant recital of the W.H. Auden poem that presses home the thought, for both the couple and the viewer, that time cannot be stopped. The sharp awareness of the transience of all things makes Celine and Jesse savour the remaining moments they still have together, but it also seems to deepen their, and the viewer's, appreciation for the poem itself. It clearly sinks in and hits home on this occasion.

What goes for the poem, I want to argue in conclusion, goes for the film as well. For it is not just the poem that expresses so eloquently the unforgiving march of time. The film itself, especially in that scene, becomes beautifully expressive of that idea and resonates more deeply as a result of it. Such moments are often among the most powerful instances of aesthetic melancholy. A work may be expressive of a difficult existential truth, and the latter may put the beauty and artistry of the work itself in sharp relief in such a way that you may come to appreciate it more deeply. That, I contend, is the extraordinary feat that all the Before films achieve and that helps to explain the hold they have on their audience.

\section{Conclusion}

Melancholy, I have argued, can be understood as the profound and bittersweet emotional experience that occurs when we vividly grasp a harsh truth about human existence in such a way that we come to appreciate certain aspects of life more deeply. It is an emotion that is frequently experienced and expressed by the two main characters of the Before trilogy. Their shared moments of melancholy are partly prompted by the environment and the circumstances in which they find themselves. But both Celine and Jesse also seek out and create such moments by the stories they tell and the reflections they engage in. That seems part of who they are as individuals and it may help to explain why they feel so drawn to each other.

Melancholy, furthermore, is effectively expressed in the trilogy through various cinematic means, such as the soundtrack, certain stylistic devices, notable motifs, and a plethora of cinematic 
references. As a result, the films are highly and uniquely expressive of that complex emotion. And, as I have suggested in the final section, this may help to explain why the films resonate deeply with some viewers and have attracted such a devoted audience. Given this intriguing parallel between the mutual attraction of the main characters and the love that viewers may feel for these films, let me end with this (rather melancholic) thought: to feel a real and profound connection and to be able to maintain that connection as time progresses is, sadly, something that happens very rarely. But when it does, it is to be cherished. ${ }^{\text {xii }}$

\section{Bibliography}

Bowring, J. (2016). Melancholy and the Landscape: Locating Sadness, Memory and Reflection in the Landscape. London: Routledge.

Brady, E. and Haapala, A. (2003). Melancholy as an aesthetic emotion. Contemporary Aesthetics, 1(1).

Joyce, James. (1969) 'The Dead.' Robert Scholes and Richard Ellmann (eds.), Dubliners. New York: The Modern Library.

Linklater, Richard. (2008) Before Sunrise \& Before Sunset: Two Screenplays. New York: Vintage.

MacDowell, J. (2013) Before Sunrise after Before Midnight: genre and gender in the Before series. Alternate Takes, http://www.alternatetakes.co.uk/?2013,9,524 (accessed 01 May 2020)

Miller, L. (2012). 'The Salon Interview: David Foster Wallace.' Stephen J. Burn (ed.), Conversations with David Foster Wallace. Jackson, MS: University Press of Mississippi. 58-65.

Robinson, J. (2005). Deeper than reason: Emotion and Its Role in Literature, Music, and Art. Oxford: Oxford University Press.

Robinson, J. (2007). 'Expression and expressiveness in art. Postgraduate Journal of Aesthetics, 4(2).

Sebald, W.G. (2011). Austerlitz. London: Penguin.

Stone, R. (2013). Walk, Don't Run: The Cinema of Richard Linklater. New York: Wallflower Press.

Tolstoy, L. (1967) 'The death of Ivan Ilych.' Great short works of Leo Tolstoy, introduction by John Bayley, translated by Louise and Aylmer Maude. New York: Harper \& Row. 247-302.

\footnotetext{
'Interestingly, on the Criterion website Linklater refers to his all-time top ten list of films as 'spirit-and-theflesh titles', which include Andrei Rublev (dir. Andrei Tarkovsky, 1969), Au hasard Balthazar (dir. Robert Bresson, 1966), Fanny and Alexander (dir. Ingmar Bergman, 1982). And in a comment that is reminiscent of the Chekhov quote he says: "I can't quite grasp the notion of how long people live and how long the earth has been here, the universe has been here, and then our little part in that. It's a beautiful poetic thing and kind of a haunting thing at the same time" (Richard Linklater in Kogonada's video essay On Cinema \& Time, 2013)
} 
ii The film titles themselves serve as a kind of ticking clock. And it's worth noting that The Clock (1945 dir. Vincente Minnelli) was a film that Linklater reportedly showed to his two leads in preparation for Before Sunrise (Stone 2013: 121).

iii As Linklater says on the commentary track of Before Midnight: 'the notion of the end of summer, holidays are over, school is starting: there was always a certain melancholy attached to that'

iv The original Shakespeare \& Co, owned by Sylvia Beach, was frequently visited by James Joyce. Beach also published Joyce's Ulysses under the imprint Shakespeare and Company. Before Sunrise takes place on the $16^{\text {th }}$ of June, which is Bloomsday (named after the main character in Ulysses). The original script of Before Sunrise included dialogue about John Huston's film adaption of Joyce's The Dead. Before Midnight heavily references Rossellini's Journey to Italy (1954), which itself is loosely based on The Dead. Interestingly, Joyce once translated Gerart Hauptmann's Vor Sonnenaufgang (Before Sunset, 1932) and also alludes to this work in Portrait of the Artist as a Young Man.

Following the previous two films, it might also lead to the realisation that the anonymous hotel rooms that we all pass through on our travels have likely been the décor of momentous changes in some people's lives.

vi The fact that 'kairos', i.e. the right moment, can be missed never to return, is, in my view, nowhere described more heartbreakingly than in the 'mushroom picking scene' of Tolstoy's Anna Karenina.

vii Truffaut's series about Antoine Doinel, the character he follows from boyhood to adulthood, was a known inspiration to Linklater. Worth mentioning in this context is that Before Sunset was originally going to open with the profoundly melancholic song L'amour à Vingt Ans, taken from Truffaut's second Doinel film, Antoine et Colette (1962).

viii Patrick is a writer and owns the house where Celine and Jesse are staying. It is quite likely that this character is named after Patrick Leigh Fermor, who owned the house where the movie was shot and who was a writer. His most famous book, A Time of Gifts, is a beautifully melancholic memoir of the author's journey through pre-war Europe.

ix In the commentary track of Before Midnight another film about marital disillusionment is mentioned (by Ethan Hawke) as a potential reference point, namely Ingmar Bergman's Scenes from a Marriage (1973). And Stone (2013: 181) notes how Linklater has acknowledged the influence of Michael Apted's deeply melancholic Up series, charting the lives of a number of children since 1964 with seven year ellipses.

${ }^{x}$ If there's one emotion that lingers after each of these films, it's melancholy. All three films leave the viewer with a bittersweet feeling (though there might be a more sweet aftertaste after the first film and more bitterness after the last film).

${ }^{x i}$ Similarly, when Celine wistfully says that they will miss the Seurat exhibition, the first image she points to is "Voie Ferrée" (Rail Road) - surely not a coincidence given the important role that trains and railroads play in the meeting and parting of Celine and Jesse.

xii I wish to thank James MacDowell, Aaron Meskin and Katrien Schaubroeck for helpful comments on earlier drafts of this paper. 